168. 医療用R I 廃亲物及び污染物の処理（第8 報）燃焼によるR I の兆散

名大医短 ○田宮 正 前越 久 津坂昌利 服部知彦

名大病院 三島 厚 名大分院 渡部羏一

血液、便、各種試料計測に於いて、計数效率をあげるため試料を燃焼减容処理する。その際ラジオアイソトープ（特 に99mTc等) が飛散すると周辺を污染させる。今回の実験に於いてはプラスチック試験官と共に燃焼させた場合にわ ずか（数\%）の減少が見受けられたが気化されないR I は此較的安全で污染発生がないことが確認された。

169. 医学部実駼施陪の排水モニタリングについて

大分医大医学部 ○久保用 久留米大医学部梅椅典良大分医大附属病院 春田隆昌

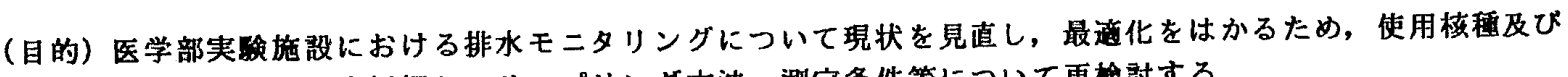

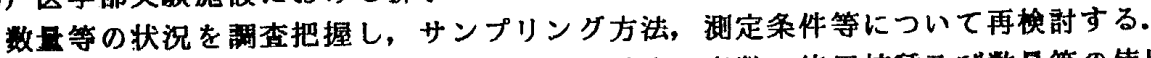

（方法）1。施設の使用開始以来 7 年間の管理区域立入者数，使用核種及び数量等の使用状況の推移を調查する.

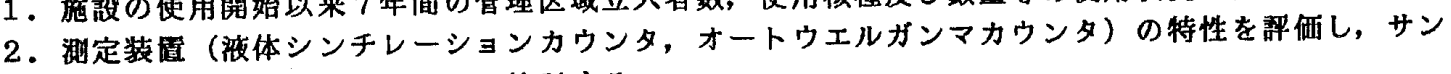
プリング条件，試料洞整方法について㛟討する。

（結果）施設の使用状況（管理区域立入者数， R I 受入件数等）については，年々增加してきた。主な使用核種 は, 使用数量の多い順に ${ }^{3} \mathrm{H},{ }^{51} \mathrm{C} \mathrm{r},{ }^{32} \mathrm{P},{ }^{35} \mathrm{~S},{ }^{125} \mathrm{I},{ }^{4} \mathrm{C},{ }^{45} \mathrm{C} \mathrm{a}$ 等であり, 最近は到 $\mathrm{P}$ の使用数 量が著しく增加してきた。一方, 排水中の許容浱度に対する核種别の寄与束は ${ }^{125} \mathrm{I}$ が最大であり, 現時 点における排水モニタリングにおいて最も考感すべき核種であると考えられる。

170. 自動現像装置のフイルム濃度補充方式 金沢医科大学病院中央放射線部 ○飛田

明 魚谷 儀一 殿田 伸一郎 山下 修

（目的）現在市䀠されている自動現像装置の处理液笺充方式は、フイルム面皘や、通過時間によって単純にコントロールす る方式である。このような方式では、撮影部位ごとに補充量を設定しない限り階調など現像処理の安定度が得られない。そ こて、フイルムサイズおよびフイルム很度を检出しフイルム搌度に比例した補充とフイルムサイズ别処理枚数の計数を行う ことが出来る装置KDR-100 を考案し、その有用性について検討した。

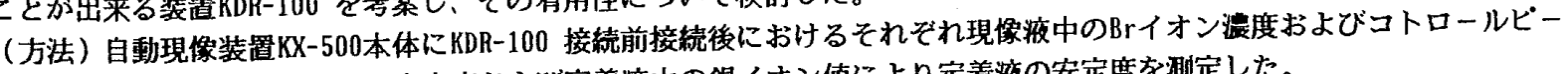
スによるG-bar 值により現像の安定度および定着㾋中の銀イオン值により定着渡の安定度を測定した。

(結果) フイルム面皘補充方式と比較してフイルム浱度補充方式はG-bar 值およびBrイオン值の変動が約1/2 となり、補充 精度 ( 2 倍) が飛羅的に向上した。フイルムサイズ別処理枚数の計数も可能であり在庫管理などのマネージントにも役立 つことが期待できる。

\title{
171. 新自動现像機の開発
}

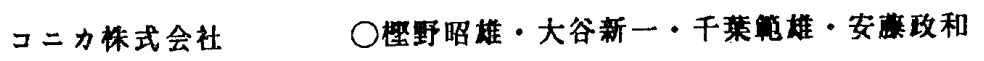

（目的）近年の医嗉䧐断において处理の迅速化が望まれている。

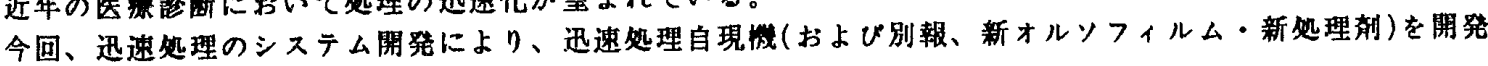
したので㫰告する。

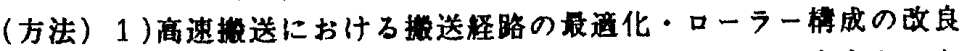

2)スクイスのランニングに扔ける初期特性踓持の向上と、キャリオーバー減少を目指したローラー棈成の 改良

3)畭媒部の/スル形状・眍置と除湿奻果の根暗化

（桔果）迅速多量处理を满足した迅速処理自现機を開発した。 